\title{
Stimulus Threshold for Providing Intraoperative Motor Evoked Potential
}

\author{
Intraoperatif Motor Uyarılmış Potansiyel Eldesi Için Uyarı Eşiği
}

\author{
๑ Emine Taşkıran, • Dilek Akyüz* \\ istanbul University-Cerrahpaşa, Department of Neurology, Istanbul, Turkey \\ *izmir Katip Çelebi University, Department of Neurology, izmir, Turkey
}

Abstract

\begin{abstract}
Aim: Intraoperative neurophysiological monitoring (IOM) has been increasingly used in surgeries associated with a risk of neurological impairment. Motor evoked potential (MEP), which is a part of intraoperative neurophysiological tests, evaluates motor function intraoperatively. Most anesthetic agents have negative effect on neurophysiologic recordings because of neuronal excitability changes. Our aim was to compare the effect of anesthetic methods consisting of volatile anesthetics and intravenous anesthetics (propofol + remifentanil) on eliciting of MEP during baseline recordings for spinal surgery which is a part of neurosurgical operations.
\end{abstract}

Methods: Fifty patients (29 males and 21 females; 21 to 85 years) who underwent spinal surgery with $10 \mathrm{M}$ in our department between 2016 and 2018 were randomly chosen for retrospective evaluation. A multipulse stimulation technique (6-9 stimuli) was used for electrical stimulation.

Results: There was a statistically significant difference in stimulus threshold in voltage stimulation between the two groups. In order to elicit muscle MEP, a higher voltage threshold had to be implemented for patients who had been given volatile anaesthesia compared to those who had been given total intravenous anesthesia (TIVA) (Mann-Whitney U test, $\mathrm{p}<0.005$ ).

Conclusion: TIVA is considered better than volatile for eliciting muscle MEPs in lower stimulus threshold. In addition, TIVA provides easy recording in all proximal and distal muscles.

Keywords: Volatile, total intravenous anesthesia, motor evoked potential, voltage stimulus threshold
Öz

Amaç: Intraoperatif nörofizyolojik monitorizasyon (IOM) nörolojik kötüleşme riski olan cerrahilerde artan sıklıkta kullanılmaktadır. İntraoperatif nörofizyolojik testlerden biri olan motor uyarılmış potansiyeller (MUP) intraoperatif olarak motor fonksiyonları değerlendirir. Birçok anestetik ajan nöronal uyarılabilirliği değiştirdiği için nörofizyolojik kayıtlar üzerine negatif etki gösterir. Amacımız, spinal cerrahide başlangıç kayıtlarda MUP uyarım eşiğine volatil ve intravenöz (propofol + remifentanil) anestezikleri içeren anestezik metodların etkisini değerlendirmektir.

Yöntemler: 2016-2018 yılları arasında IOM eşliğinde spinal cerrahi için opere edilen rastgele 50 hasta (29 erkek ve 21 kadın; 21-85 yaş) retrospektif değerlendirme için çalışmaya alındı. Elektriksel uyarım için çoklu uyarım (6-9 uyarım) tekniği kullanıldı.

Bulgular: Sabit voltaj uyarımda uyarım eşiği için gruplar arasında istatiksel anlamlı farklılık saptandı. Volatil anestezik ile kas MUP eldesi için gereken uyarım eşiği TIVA grubundan daha yüksekti (Mann-Whitney U testi, $p<0,005$ ).

Sonuç: Total intravenöz anestezi daha düşük uyarım eşiğinde kas MUP eldesi için volatil anesteziğe daha üstün gözükmektedir. Ek olarak, TIVA proksimal ve distal kasların hepsinde daha kolay MUP eldesi sağlamaktadır.

Anahtar Sözcükler: Volatil, total intravenöz anestezi, motor uyarılmış potansiyel, voltaj uyarım eşiği
Address for Correspondence/Yazışma Adresi: Emine Taşkıran, İstanbul UniversityCerrahpaşa, Department of Neurology, İstanbul, Turkey E-mail: dreminetaskiran@gmail.com ORCID: orcid.org/0000-0002-4402-7606 Received/Geliş Tarihi: 16 June 2019 Accepted/Kabul Tarihi: 08 October 2019
${ }^{\circ}$ Copyright 2020 by The Medical Bulletin of istanbul Haseki Training and Research Hospital The Medical Bulletin of Haseki published by Galenos Yayınevi.

${ }^{8}$ Telif Hakkı 2020 istanbul Haseki Eğitim ve Araştırma Hastanesi Haseki Tıp Bülteni, Galenos Yayınevi tarafından yayınlanmıştır. 


\section{Introduction}

Intraoperative neurophysiological monitoring (IOM), which aims the best quality of life after surgery, has been increasingly used in new advanced concept of neurosurgery, cardiovascular surgery and thyroid surgery (1-4). Primary intraoperative neurophysiological studies are motor- and sensory-evoked potentials (MEP and SEP), electromyography and, electroencephalography. Among these, MEP presents the functionality of motor pathway from the cortex to muscles during the surgery. Loss of MEP and decreased MEP amplitude indicate postoperative motor worsening. Thus, MEP evaluation during surgery is necessary for patients with lesions that may affect the motor pathways. Most of anesthetic agents used intraoperatively change excitability of the neuroaxis at the cortical, subcortical and spinal levels and have negative effect on neurophysiological recordings (5).

This study aims to compare the effect of anesthetic methods consisting of volatile anesthetics and intravenous anesthetics (propofol + remifentanil) on eliciting MEP during spinal surgery.

\section{Methods}

\section{Subject and Data Collection}

Fifty patients who underwent spinal surgery with the aid of IOM were included in this study. Sevoflurane, which is one of the most commonly used volatile anesthetics, was used in 20 patients and propofol plus remifentanil in 30 patients. Demographical characteristics, neurological examination findings, diagnosis, surgical level, anesthesia type, and intraoperative neurophysiological recordings of 50 patients were retrospectively evaluated. Those having a hemoglobin level of $<10 \mathrm{gr} / \mathrm{dL}$ and hematocrit concentration of $<35 \%$ in preoperative evaluations were excluded.

\section{Transcranial Motor Evoked Potentials}

MEPs were elicited by stimulating the motor cortex from the scalp and recording from muscles. Stainless steel needle electrodes (13-19 mm, Xi'an Friendship Medical Company) and corkscrew electrodes were used for MEP responses respectively. Stimulation was performed using a multipulse stimulation technique based on a train of 6 to 9 stimuli with $4 \mathrm{~ms}$ interstimulus interval (ISI), pulse width of $50 \mu \mathrm{s}$, and an intensity between $200 \mathrm{~V}$ and 600 $\mathrm{V}$, delivered at C1-C2 for right (R) extremity and C2-C1 for left (L). C3-C4/C4-C3 montage was used when not being gained with $\mathrm{C} 1-\mathrm{C} 2 / \mathrm{C2}_{-}-\mathrm{C} 1$ montage. Out of these two groups, the one with the lowest voltage threshold to elicit mMEP was used. Abductor pollicis brevis (APB), tibialis anterior (TA) and abductor halluces (AH) were recorded in all patients. Trapezius, deltoid, biceps brachi, extensor digitorum communis and iliopsoas, quadriceps femoris (QF), vastus lateralis, gastrocnemius, and sphincter ani externus muscles were added depending on surgical level. Evaluation was made for muscles having the lowest muscle threshold (APB, TA and, AH).

The Cadwell elite IOM system was used for neurophysiological recordings.

Total intravenous anesthesia (TIVA) using propofol $(1.5-2 \mathrm{mg} / \mathrm{kg}$ for anesthesia induction and $6-10 \mathrm{mg} /$ $\mathrm{kg} / \mathrm{h}$ for maintenance) plus remifentanil $(0.15 \mu \mathrm{gg} / \mathrm{kg} /$ min) was used in 30 patients while inhalation anesthesia (sevoflurane, minimum alveolar concentration (MAC) maximum 0.5, BIS 40-60) was used in 20. A short-acting muscle relaxant (rocuronium, $0.5 \mathrm{mg} / \mathrm{kg}$ ) was used only for endotracheal intubation. Satisfactory recovery from neuromuscular block was monitored by the train-offour technique before MEP recording. In addition, mean arterial pressure, end-tidal carbon dioxide and oxygen concentration were monitored by the anesthesia team before eliciting MEP responses in all cases.

All procedures were performed in accordance with the 1964 Helsinki Declaration and its later amendments. Due to the fact that the study was retrospective, ethical committee approval was not obtained. Written informed consent was obtained from the patients.

\section{Statistical Analysis}

The statistical package for the social sciences (SPSS) 22.0 was used for data analysis. For descriptive statistics, the measures used were percentage distributions for categorical variables, and means (medians) with standard deviation (ranges) and, ranges for continuous variables. Frequency distributions were compared using the chisquare test and means by independent samples t-test and one-way analysis of variance (ANOVA) for normal variables, The Mann-Whitney $\mathrm{U}$ test and Kruskal-Wallis $\mathrm{H}$ test were used for non normal variables.

\section{Results}

The mean age of the patients (29 males and 21 females) was 48.7 years (range: 21-85 years). Bilateral extremities of 50 patients were evaluated, yielding a data set of 100. All patients had a hemoglobin level of $>10 \mathrm{~g} /$ $\mathrm{dL}$. The diagnosis and surgical levels in the two groups are shown in Table 1.

\section{TIVA Group}

Eight patients had an intradural extramedullary mass, five had an intramedullary mass, two had an extradural mass, nine had stenosis, and six patients had fracture. Operation levels were at the cervical spinal level in 15, thoracal in nine and, lumbar in six. Fourteen patients had motor deficits preoperatively, with three of them having 
$<3 / 5$ motor power. Mean voltage value for TIVA group was $325 \mathrm{~V}$, ranged from 170 to 450. In 60 extremities, APBMEP was elicited in all except 2 which had severe motor paralysis. AH-MEP was not achieved in 6 (3 R, 3L) which had severe motor paralysis $(<2 / 5)$ preoperatively and QFMEP in 11 extremities, with eight out of 11 had motor paralysis at the preoperative neurological examination. MEP response variability was not detected in this group.

\section{Volatile Group}

Eight patients had an intradural extramedullary mass, 1- intradural intramedullary tumor, 1- extradural tumor, 7- stenosis, and 3-fracture. Operation levels in this group were cervical spinal level in 7, thoracal in 3, lumbar in 9 and, sacral in one. Seven patients had mild $(>3 / 5)$ motor deficit preoperatively. Mean voltage value for volatile group was 423V, ranged from 330 to 600 . MEP response variability was detected in two. R APB-MEP and bilateral proximal muscle MEPs (deltoid, biceps brachi) were elicited at the baseline recording in all except one having C1-C2 meningioma and no neurological deficit preoperatively. AH-MEP could not be elicited in one patient having severe motor deficit preoperatively and QF-MEP in 5 (3 R, 2 L) with three of those had motor deficit in preoperative neurological examination.

There was a statistically significant difference in stimulus threshold in voltage stimulation between the two groups (Mann-Whitney $U$ test, $p<0.005$ ). Presence of motor deficit preoperatively did not have an impact on the increase of required voltage stimulation in the two groups.

\section{Discussion}

This study showed that voltage threshold to elicit MMEP with the multipulse stimulation technique-a train of 6 to 9 with an ISI of 4 ms, pulse width of 50 $\mu \mathrm{s}$-in patients who had been given volatile anaesthesia

\begin{tabular}{|l|l|l|}
\hline \multicolumn{3}{|l|}{ Table 1. Diagnosis and surgical levels for two groups } \\
\hline Diagnosis & $\begin{array}{l}\text { Number of } \\
\text { patient/TIVA }\end{array}$ & $\begin{array}{l}\text { Number of } \\
\text { patient/volatile }\end{array}$ \\
\hline Intradural mass & 9 & 7 \\
\hline Intramedullary mass & 4 & 2 \\
\hline Extradural mass & 2 & 1 \\
\hline Stenosis & 9 & 7 \\
\hline Fracture & 6 & 3 \\
\hline Surgical level & $\begin{array}{l}\text { Number of } \\
\text { patient/TIVA }\end{array}$ & $\begin{array}{l}\text { Number of } \\
\text { patient/volatile }\end{array}$ \\
\hline Cervical & 15 & 7 \\
\hline Thoracal & 9 & 3 \\
\hline Lumbar & 6 & 9 \\
\hline Sacral & 0 & 1 \\
\hline TIVA: Total intravenous anesthesia & & \\
\hline
\end{tabular}

was higher than that of TIVA. There are some studies evaluating suppressive effect of inhalation agents on MEPs (6). They generally pointed out reduction in MEP amplitude with volatile anesthetic usage in different MAC levels. In their study randomizing patients to three groups to receive halothane (HAL), isoflurane (ISO), or sevoflurane, Sekimoto et al. (6) reported that the amplitudes of MEPs were significantly reduced by all agents at 1.0 MAC, with the effect being less in HAL at $0.5 \mathrm{MAC}$. In this study, we focused on stimulus threshold for eliciting MEP response by the multipulse stimulation technique (6 to 9 stimuli with an ISI of $4 \mathrm{~ms}$, pulse width of $50 \mu \mathrm{s})$ by sevoflurane agent at $<0.5 \mathrm{MAC}$ and TIVA. There was a statistically significant difference in stimulus threshold in voltage stimulation between the two groups (Mann-Whitney $U$ test, $\mathrm{p}<0.005$ ).

It is known that obtaining MEP response in lower extremities is difficult in patients with preoperative motor deficit. Chen et al. (7) reported that the success rate for obtaining reliable MEP response was $94.8 \%$ for upper extremities and $66.6 \%$ for lower extremities and it was only $39.1 \%$ for lower extremities in patients with preoperative motor deficit. This challenge could be demonstrated in patients who had been given volatile anaesthesia. In contrast, presence of preoperative motor deficit did not have an impact on the increase of required voltage stimulation in the two groups although provided MEP was much lower in patients with preoperative motor weakness in this study. This might be explained by very mild motor paralysis $(>4 / 5)$ in our patients.

MEP response variability was detected in two patients of only volatile group in this study. Volatile agents decrease the possible motor neuron recruitment in anterior horn of the spinal cord and affect the propagation of a peripheral motor response negatively. Thus, volatile agents interfere with reliable MEP acquisition. Pelosi et al. (8) confirmed this situation in their study reporting that reliable recordings were present in 14 of 23 patients who received volatile agents and 28 of 29 who received propofol. In addition, bilateral MEP recruitment ratios were higher with propofol than with volatile anaesthesia. TIVA offers obvious advantages in obtaining MEP response and reliable acquisition during surgery.

Isofluran, enfluran, desfluran, sevoflurane and halotan are volatile anesthetics. In general, all have similar effects on evoked potentials. In this study, we evaluated the effect of sevoflurane on MEP acquisition and response variability. Volatile anaesthetics have an effect on pyramidal neurons, cortical interneurons, corticospinal axons and, alfa motor neuron (9-11). Inhibition via neocortical GABA-A receptors ensures cortical suppression $(9,10)$. Suppressing effect on motor 
pathway at the corticospinal and spinal level is based on blocking synaptic transmission over alpha motor neurons in the spinal cord and depressing $\mathrm{Na}$ transmission at the Ranvier nodes of corticospinal axons (11). Propofol's advantage over volatile anaesthesia is that it has a negligible effect on MEP at the spinal level. As seen in our study, MEP acquisition is achieved more easily and with lower voltage stimulation under TIVA.

Volatile anesthetics depress excitatory synaptic transmission by inhibiting presynaptic voltage-gated $\mathrm{Na}^{+}$channels at clinical concentrations. In contrast, the intravenous anesthetic propofol inhibits $\mathrm{Na}^{+}$channels only at supratherapeutic concentrations (12). Some new sedatives such as alpha2-agonist dexdemetomidine have been come up to decrease propofol dosage $(13,14)$.

\section{Study Limitations}

All patients with and without motor weakness were included in this study. It would better to include patients with normal MEP findings without motor weakness for comparing the voltage stimulus thresholds for eliciting muscle MEPs between the two groups.

\section{Conclusion}

As a consequence, at a current time, TIVA is considered to be better than volatile anesthetic for monitoring muscle MEPs. Even in cases in which TIVA is used, however, it should be considered that higher levels of propofol may cause suppression on alpha motor neuron at the spinal level and thus misinterpretation of MEP loss or amplitude decreasing in this setting. With developing new anaesthetic agents, new studies aiming to evaluate their suppressing effect on MEPs and/or other evoked potentials would be required.

\section{Authorship Contributions}

Concept: E.T. Design: E.T. Data Collection or Processing: E.T., D.A. Analysis or Interpretation: E.T. Literature Search: E.T., D.A. Writing: E.T., D.A.

Conflict of Interest: No conflict of interest was declared by the authors.

Financial Disclosure: The authors declared that this study received no financial support.

\section{References}

1. Harvey RE. Neurological Outcomes and Neuromonitoring in Cardiac Surgery. Int Anesthesiol Clin 2018;56:21-46.

2. Guarracino F, Baldassarri R, Zanatta P. Current Status of Neuromonitoring in Cardiac Surgery. Curr Anesthesiol Rep 2017;7:259.
3. Roldan MLAS, Tellez MJ, Ulkatan S, Sinclair CF. Continuous Vagal Neuromonitoring Using the Laryngeal Adductor Reflex: Can Preincision Dyssynchrony Predict Intraoperative Nerve Behavior? Otolaryngol Head Neck Surg 2019:194599819835781.

4. Naytah M, Ibrahim I, da Silva S. Importance of incorporating intraoperative neuromonitoring of the external branch of the superior laryngeal nerve in thyroidectomy: A review and meta-analysis study. Head Neck 2019;41:2034-41.

5. Simon M. The effects of anesthetics on intraoperative neurophysiology studies. In: Intraoperative Neurophysiology: A Comprehensive Guide to Monitoring and Mapping. Edited by Simon M: New York; Demos Medical. 2010, pp 325-32.

6. Sekimoto K, Nishikawa K, Ishizeki J, Kubo K, Saito S, Goto F. The effects of volatile anesthetics on intraoperative monitoring of myogenic motor-evoked potentials to transcranial electrical stimulation and on partial neuromuscular blockade during propofol/fentanyl/nitrous oxide anesthesia in humans. J Neurosurg Anesthesiol 2006;18:106-11.

7. Chen $X$, Sterio D, Ming $X$, et al. Success rate of motor evoked potentials for intraoperative neurophysiologic monitoring: effects of age, lesion location, and preoperative neurologic deficits. J Clin Neurophysiol 2007;24:281-5.

8. Pelosi L, Stevenson M, Hobbs GJ, Jardine A, Webb JK. Intraoperative motor evoked potentials to transcranial electrical stimulation during two anaesthetic regimens. Clin Neurophysiol 2001;112:1076-87.

9. Hentschke H, Schwarz C, Antkowiak B. Neocortex is the major target of sedative concentrations of volatile anaesthetics: strong depression of firing rates and increase of GABAA receptor-mediated inhibition. Eur J Neurosci 2005;21:93-102.

10. Osawa M, Shingu K, Murakawa M, et al. Effects of sevoflurane on central nervous system electrical activity in cats. Anesth Analg 1994;79:52-7.

11. Burke D, Bartley K, Woodforth IJ, Yakoubi A, Stephen JP. The effects of a volatile anaesthetic on the excitability of human corticospinal axons. Brain 2000;123:992-1000.

12. Rehberg B, Duch DS. Suppression of central nervous system sodium channels by propofol. Anesthesiology 1999;91:51220.

13. Mark G. Papich. Dexmedetomidine Hydrochloride. Saunders Handbook of Veterinary Drugs. 4th ed. Missouri: Elsevier; 2016.

14. Scott-Warren VL, Sebastianc J, Dexmedetomidine: its use in intensive care medicine and anaesthesia. BJA Education 2016;16:242-6. 